\title{
Palaeoecological analysis and environmental development of the Kostenets Neogene Basin, Bulgaria
}

\section{Nadja Ognjanova-Rumenova, Marlena Yaneva}

Geological Institute, Bulgarian Academy of Sciences, Acad. G. Bonchev Str., Bl. 24, 1113 Sofia, Bulgaria; e-mails: nognjan@geology.bas.bg; marlena@geology.bas.bg

(Accepted in revised form: August 2018)

\begin{abstract}
A comprehensive lithological and biostratigraphic investigation into diatoms and chrysophycean stomatocysts was conducted on two boreholes from the central zone of the Kostenets Neogene Basin. The diatom flora consists of 105 species, varieties, and forms. The results of these different analyses presented herein indicate three successive stages in the palaeoenvironmental development of the Kostenets Basin, at the end of the Miocene and the beginning of the Pliocene.
\end{abstract}

Ognjanova-Rumenova, N., Yaneva, M. 2018. Palaeoecological analysis and environmental development of the Kostenets Neogene Basin, Bulgaria. Geologica Balcanica, 47 (2), 3-21.

Keywords: diatoms, chrysophycean stomatocysts, sedimentology, palaeoecology, Kostenets Neogene Basin, Bulgaria.

\section{INTRODUCTION AND \\ GEOLOGICAL SETTING}

The sediments of the Neogene Kostenets Basin fill the Kostenets graben (Vâlkova and Spiridonov, 1979), which is $25 \mathrm{~km}$ long and up to $6.5 \mathrm{~km}$ wide. The sediments have a maximum thickness of $650 \mathrm{~m}$.

The coal deposit near the village of Gabrovitsa had long been known to the local people, but they did not benefit from it (Konjaroff, 1932). For the first time, Georgi Zlatarski (1927), in Geology of Bulgaria, mentioned a Tertiary basin around the villages of Kostenets, Gabrovitsa, and Malko Belovo. He compared it to the Sofia Basin. Bonchev (1906), in "Petrographic sketch of the High Balkan, Sredna Gora and Ihtiman Sredna Gora Mountain (M 1:300 000)", noticed the coal deposit near Gabrovitsa with the same distribution in the basin's frames. Later on, the same author mentioned again the coal in the area and described a few thin layers located close to each other, the lowermost one being the thickest (Bonchev, 1917). He determined the coal as black-brown, with a conchoidal fracture, and still showing wood fabric. Lazar Vankov (in: Konjaroff, 1932) described the same Tertiary basin as Zlatarski and Bonchev but without mentioning the coal deposit. More detailed characteristics of the coal and the hosting sediments were published by Konjaroff (1932). Along with the coal characteristic, he gave an adequate description of the Tertiary sediments, referring them to the Pliocene, and of their distribution. He described variegated, mostly green clays, sandy in various degrees, and enriched in mica.

In 1961, Grânčarov mapped the same area as the Pliocene Gabrovitsa coal-bearing series. He found fossil flora in the clays above the coal (e.g., Juglans cinerea, Acer sp., Populus sp., Salix sp.), as well as a molar of Mastodon borsoni Hays, which dates these sediments as Dacian.

Vâlkova and Spiridonov (1979) defined three stages of development of the North Rhodope fault zone. The second stage occurred during the Pliocene and resulted in intensive longitudinal and transversal faulting along the northern slopes of the Rhodope and Rila mountains and in formation of a sedimentary basin. The deposits have been divided into three units based on their lithology and 
facies: (1) breccia-conglomerates with coarse sandy intercalations; (2) alternation of sandstones, clayey sandstones, coaly clays and coal with relicts of Mastodon borsoni Hays, and abundant fossil leaves that suggest a Pliocene age; pollen analysis gave the same age; (3) loose breccia-conglomerates.

Formal lithostratigraphic units were introduced by Vatsev and Jordanov (1996) as follows:

- Beli Dol Formation - composed of cobble to pebble conglomerates interbedded with coarse-grained sandstones and gravelites with thickness of 100-120 m and probably of Maeotian age;

- Gabrovitsa Formation - composed of alteration of coarse- to fine-grained sandstones, clayey siltstones, silty clays, diatomaceous clays, coal shales, and lignite coal beds, with thickness of 100-170 m, Pontian in age based on vertebrate fauna and fossil flora (Grânčarov, 1961; Kojumdgieva et al., 1984). Studies on the diatomaceous flora there (Ognjanova-Rumenova and Yaneva, 2003; Ognjanova-Rumenova, 2004) have proven a late Pontian age of the diatomaceous clays;

- Dolno Pole Formation - composed of a gradual transition of sandstones and gravelites into sandstones and conglomerates with thickness of 100-250 m, and probable Pontian age;
- Drandaritsa Formation - composed of cobble to boulder breccia-conglomerates, conglomerates, and layers of coarse- to medium-grained sandstones with thickness of 50-100 m, and probable Pliocene age.

The deposits of the Gabrovitsa Formation are subject of the present study.

On the geological map in scale 1:50 000, the Neogene sediments were united into one informal lithostratigraphic unit: the sandstone and conglomerate unit (Naydenov et al., 2008), which includes the Pleistocene "Gabrovitsa coal-bearing series" and the Pliocene-Pleistocene "Sestrimo conglomerate unit” introduced by Grânčarov (1961). On the geological map of Bulgaria in scale 1:100 000 (Dimitrova and Katskov, 1990), the herein-distinguished formations were described as breccia-conglomerate-sandstone and coal-bearing unit.

\section{MATERIAL AND METHODS}

Sediments collected from two boreholes, C-2 and C-3, were studied. The boreholes are located south from the village of Gabrovitsa (Fig. 1). Borehole C-2 was sampled from $28.40 \mathrm{~m}$ to $295 \mathrm{~m}$, and borehole C-3 - from $207 \mathrm{~m}$ to $283 \mathrm{~m}$. Samples were submitted to grain-size analysis by an automatic

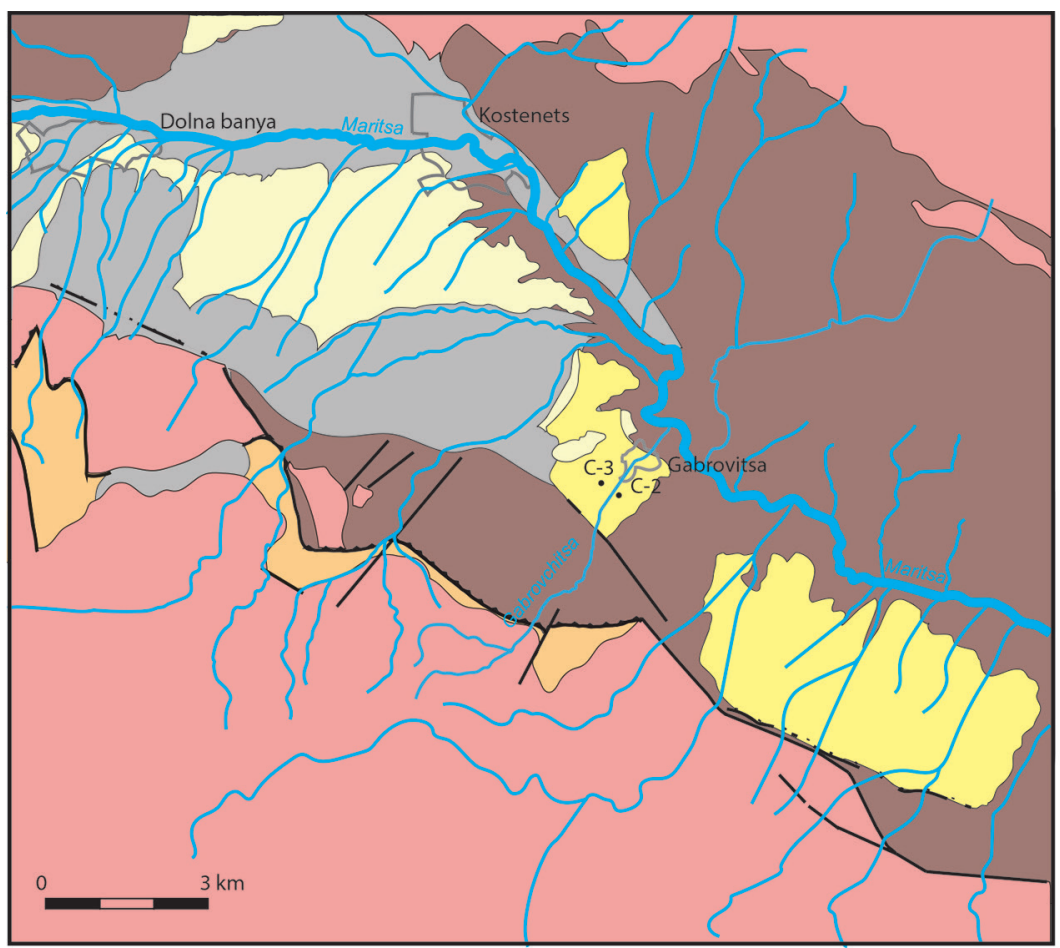

Quternary - gravel and sand

Neogene-Quaternary - proluvial and alluvial deposits

Neogene - Conglomerate sandstone unit

Palaeogene - Sandstone unit

Bedrock - metamorphic rocks

Bedrock - igneous rocks

$\checkmark$ Fault

Thrust fault

- Uncertain fault

- C-2 Borehole

Fig. 1. Schematic geological map of the Kostenets Basin with locations of investigated boreholes (after Dimitrova and Katskov, 1997, and Naydenov et al., 2008). 
sieving system FRITSCH ANALYSETTE PRO 3 for fractions larger than $0.063 \mathrm{~mm}$, and pipette analysis was used for fractions smaller than $0.063 \mathrm{~mm}$. We used the Udden-Wentworth scale (Wentworth, 1922) to separate the following fractions: gravel $>2 \mathrm{~mm}$, sand $2-0.063 \mathrm{~mm}$, silt $0.063-0.004 \mathrm{~mm}$, and clay $<0.004 \mathrm{~mm}$. Cumulative curves were drawn and statistical parameters of grain-size distribution were calculated according to Folk and Ward (1957): mean size (Mz), standard deviation (sorting $\sigma 1$ ), and skewness Sk (symmetry of distribution). The mineralogical composition of sand was investigated under the polarizing light-microscope. We studied the sand above and below the diatomaceous beds to clarify the environmental condition during their deposition.

A total of 125 samples were collected for diatom analysis, of which only 18 samples were diatombearing: borehole C-2 (28.40-43.70 m), and borehole C-3 (268.80-275.00 m). The preparation and analysis of diatom samples followed the methods of Ognjanova-Rumenova (1991). The relative abundance of diatoms was estimated by Schrader's (1973) scale Preparation for scanning electron microscopy (SEM) followed Hasle and Fryxell (1970) and samples were examined on a Philips 515 at Freie Universität Berlin and a Jeol JSM 5510 at Sofia University. The terminology used herein is principally that of Anonymous (1975) and Ross et al. (1979), with a few additions of recent proposals. The spectra of physicochemical tolerance of the identified recent diatom taxa were based mainly on Lowe (1974) and Van Dam et al. (1994). The ecological spectra covered the habitat, the halobity, the active water reaction $(\mathrm{pH})$, nutrients, temperature, and geographical distribution. The percentage ratio of diatom frustules to chrysophycean stomatocysts was applied as an index of trophic status (Smol, 1985).

\section{RESULTS AND DISCUSSION}

\section{Sedimentological characteristic}

The presence and similarity between diatom-bearing beds gives a good basis to correlate both boreholes. Thus, the sedimentary succession is more complete and representative (Fig. 2).

The sedimentary succession starts with weathered bedrock, followed by a breccia composed of bedrock clasts among the weathered clayey material with thickness of $20 \mathrm{~m}$. Breccias have clastsupported structure. Clasts are of weathered green rocks with sizes about $2-4 \mathrm{~cm}$. Matrix is of weathered detritic material from the same rocks of sandyclayey size.
An alternation of sand and slightly cemented sandstones, gravels with sandy clays and clayey sands takes the next $154 \mathrm{~m}$ of the drill-core. Sand and sandstones are grey to light grey in colour. Siltstones are more greenish-grey. Grains and clasts are sub-angular to sub-rounded. The mineralogical composition of the sand fraction is dominated by quartz, followed by feldspars, chlorite, and micas. This fraction is abundant in amphibole, zircon, and epidote minerals. The silty rocks are composed of equal amounts of quartz and feldspars, micas, sericitized micas, and clay minerals. They contain about $7-12 \%$ sand-sized grains. Pebble conglomerates, matrix-supported, with clasts ranging from $5 \mathrm{~mm}$ to $10 \mathrm{~mm}$, appear between $213 \mathrm{~m}$ and $208 \mathrm{~m}$ in borehole C-2. This interval between $275 \mathrm{~m}$ and $131 \mathrm{~m}$ in borehole C-2 could be referred to the Beli Dol Formation of Vatsev and Yordanov (1996).

The upper part of the succession, above the 131$\mathrm{m}$ level in C-2 and between $283 \mathrm{~m}$ and $233 \mathrm{~m}$ in C-3, represents an alternation of fine sand, silty clays, and clayey siltstones with beds of diatomaceous clays. Clays and siltstones in this interval are beige-brownish, light greyish-beige, or beige. They contain a various amount of coalified plant detritus, as some are coaly clays. Between $113 \mathrm{~m}$ and 107 $\mathrm{m}$ in C-2, coarse-grained gravel layers were registered. The diatomaceous clays are light, greyishbrown, representing a mixture of clay minerals, diatom frustules, silt-sized quarts, feldspars, and micas. Diatomaceous clay shows two structural types: massive structure with spherical parting; and laminated structure where 1-2 mm laminae are enriched in diatoms or clays. These sediments are most probably a part of the Gabrovitsa Formation.

Coarse sediments were described in the upper part of the sampled section of C-3 between $233 \mathrm{~m}$ and $207 \mathrm{~m}$, namely conglomerates, sands, sandy clays, and clayey siltstones, which can be easily referred to the Dolno Pole Formation of Vatsev and Jordanov (1996).

Results from the grain-size analysis are plotted on a Sand-Clay-Silt triangular diagram (Fig. 3). The grain-size composition of sand samples referred them to the group of silty sands, according to the sandstone classification of Folk (1954). They are poorly to very poorly sorted, with near symmetrical or fine skewness.

The grain-size distribution is shown on cumulative curves on Fig. 4. The character of the curves is very similar, which suggests similar hydrodynamic conditions during the sand deposition.

Calculated statistical parameters (Table 1) show that mean-size $\mathrm{Mz}$ is $3.85 \phi$ up to $3.97 \phi$, which refers these samples to very fine sands. They are 


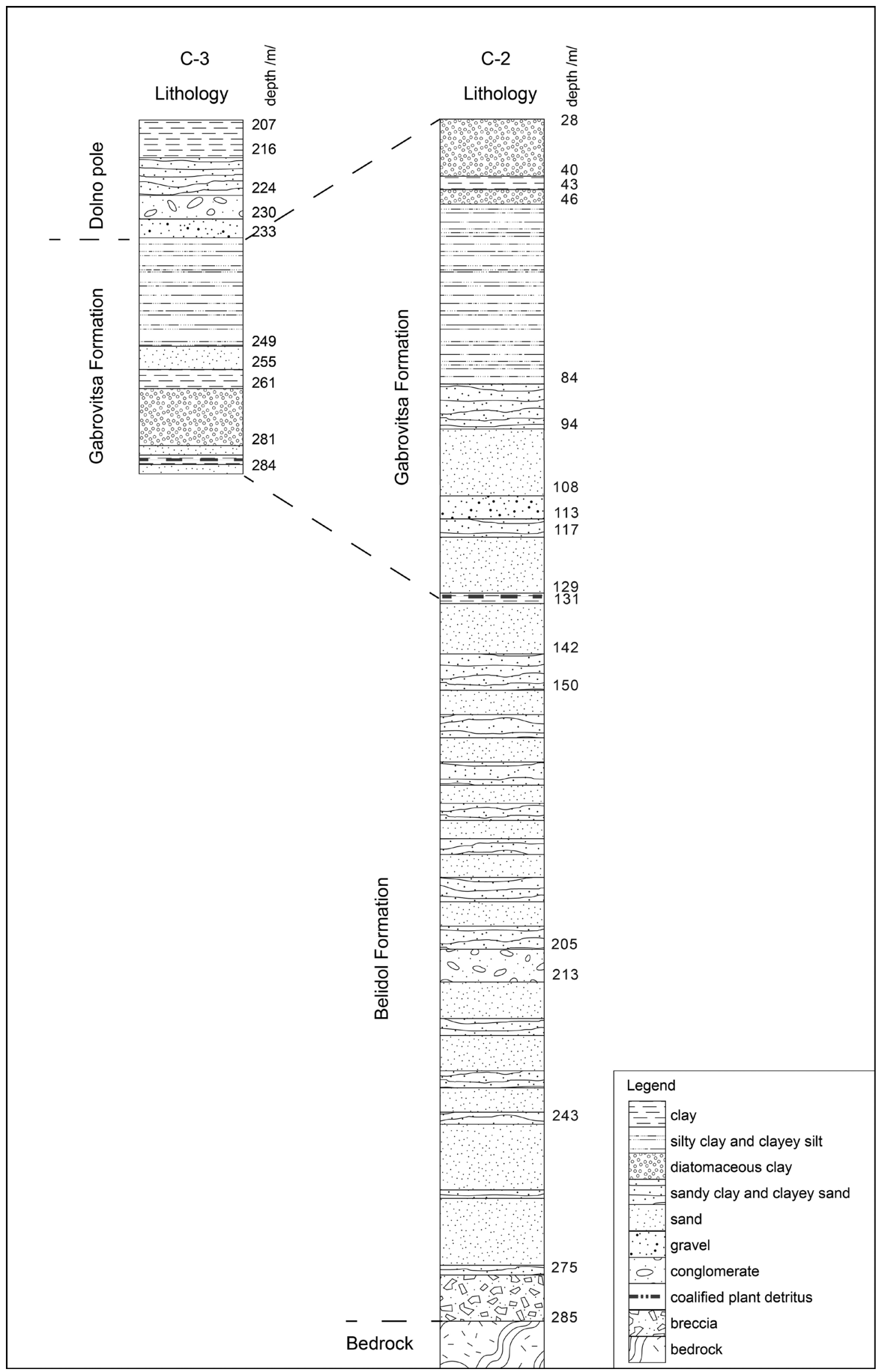

Fig. 2. Lithostratigraphic columns of boreholes C-2 and C-3. 


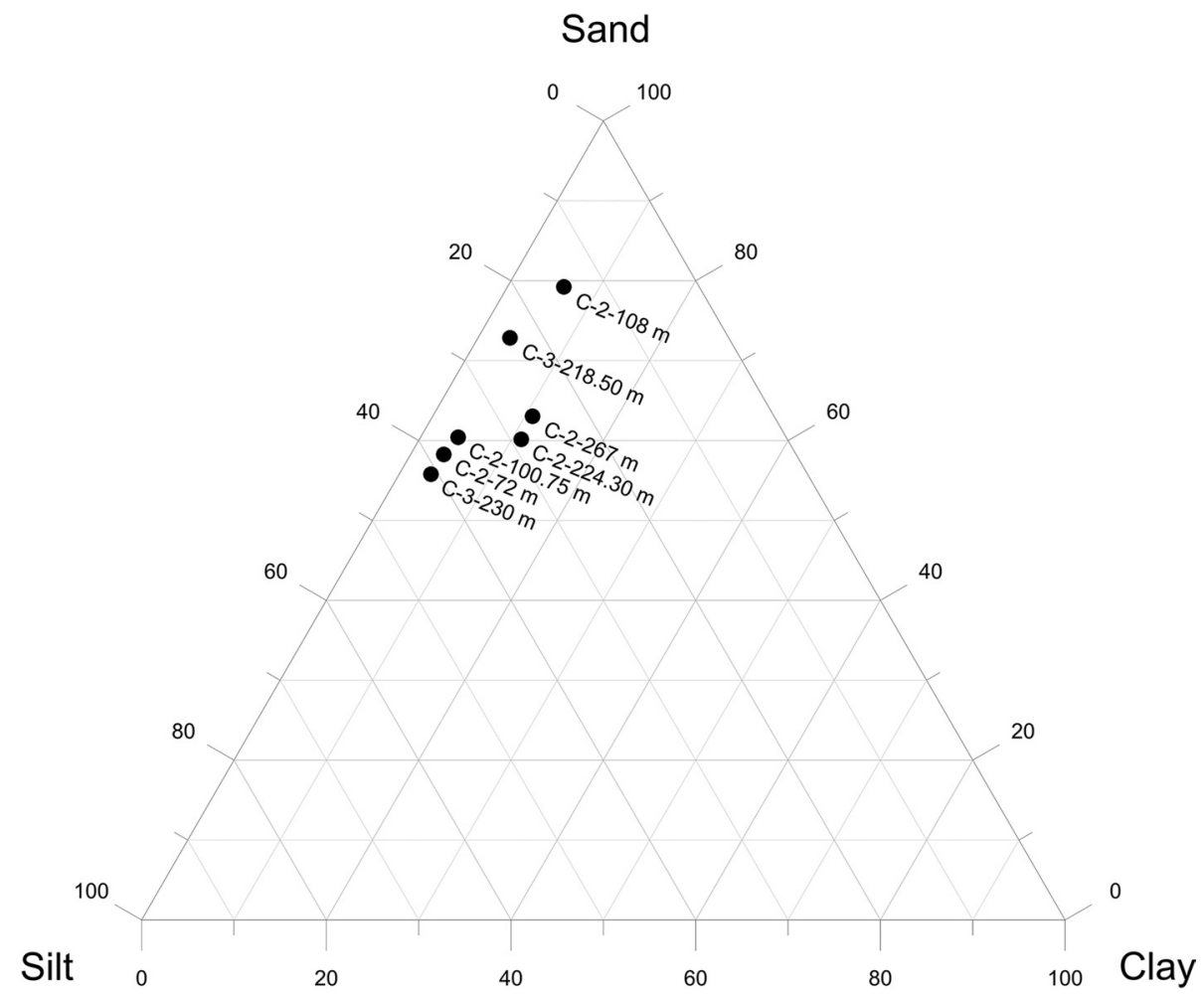

Fig. 3. Triangle diagram Sand-Silt-Clay.

poorly or very poorly sorted ( $\sigma 1$ is between $1.4 \phi$ and $2.7 \phi$ ), with near-symmetrical to coarse skewness (Sk $0 \phi$ and $-0.30 \phi$ ). A chart of the relationships of mean grain diameter $(\mathrm{Mz})$ versus standard
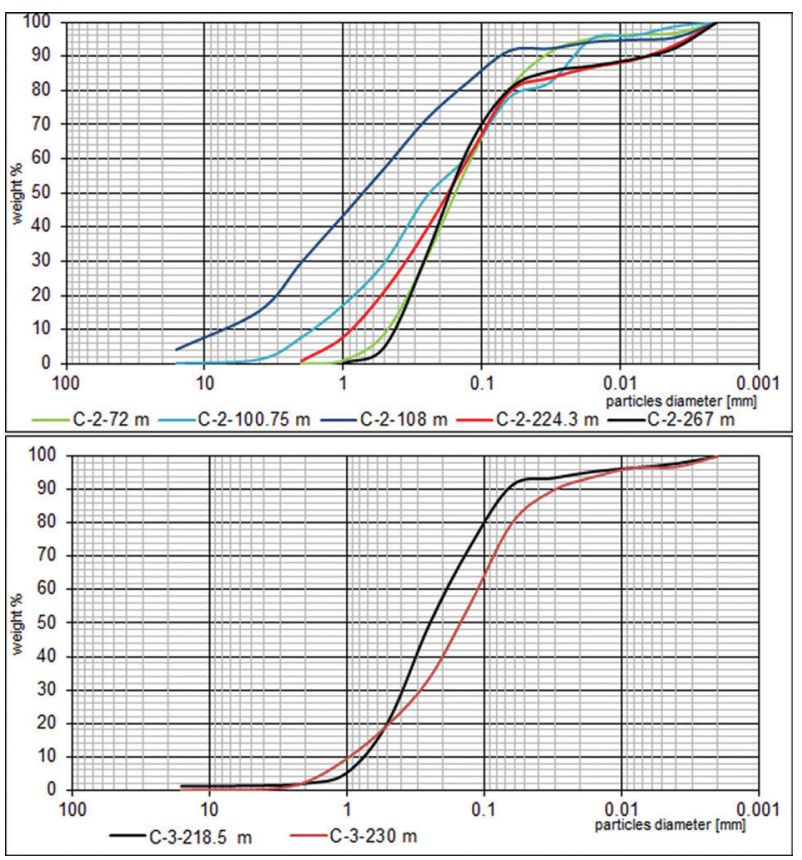

Fig. 4. Cumulative curves of the grain-size distribution. deviation $(\sigma 1)$ of Folk \& Ward textural parameters (modified by Ludwikowska-Kędzia, 2000; Mycielska-Dowgiałło, 2007; Mycielska-Dowgiałło et al., 2011) was drawn (Fig. 5). Samples clearly group into two main groups: a) deposited in a river channel; and b) overbank deposits. Most of the samples could be interpreted as deposited in a riverbank, and only one in a river channel (C-2, $108 \mathrm{~m})$. These results were proven by the cumulative curve characteristics.

\section{Analysis of the diatom flora with taxonomical remarks}

Table 2 lists the classification order after Glezer et al. (1988), with additions by Round et al. (1990). The total number of the diatom taxa recorded in the diatom-bearing samples from the surveyed boreholes is 105 . They were referred to 43 genera belonging to the classes Coscinodiscophyceae, Fragilariophyceae, and Bacillariophyceae. Only two forms could not be identified at species level, and they were listed as "sp.". In terms of taxonomic diversity, the classes Fragilariophyceae and Bacillariophyceae prevailed (95.2\%). The order Naviculales showed the greatest generic diversity and includes the genera Navicula Bory, Placoneis Mereschkowsky, Hippodonta Lange-Bertalot, Metzeltin \& Witkows- 
Table 1

Grain-size classes and statistical parameters of grain-size distribution according to Folk and Ward (1957)

\begin{tabular}{lcccccccl}
\hline Sample & Clay & Silt & Sand & Gravel & Mz & $\sigma 1$ & Sk & \\
\hline C-2-72 m & 3.60 & 38.13 & 58.27 & 0.00 & 2.94 & 1.39 & 0.24 & poorly sorted, fine skewed \\
C-2-100.75 m & 4.00 & 35.04 & 59.63 & 1.33 & 2.35 & 2.36 & 0.13 & $\begin{array}{l}\text { very poorly sorted, near symmetrical } \\
\text { skewness }\end{array}$ \\
C-2-108 m & 5.15 & 12.37 & 66.90 & 3.73 & 0.61 & 3.04 & 0.17 & very poorly sorted, fine skewed \\
C-2-224.3 m & 11.04 & 28.80 & 60.16 & 0.00 & 2.72 & 2.46 & 0.28 & very poorly sorted, fine skewed \\
C-2-267 m & 10.80 & 26.13 & 63.07 & 0.00 & 2.98 & 2.03 & 0.51 & very poorly sorted, strongly fine skewed \\
C-3-218.5 m & 3.40 & 23.34 & 71.88 & 1.20 & 2.46 & 1.31 & 0.55 & poorly sorted, strongly fine skewed \\
C-3-230 m & 3.40 & 40.66 & 55.67 & 0.21 & 2.63 & 1.89 & -0.06 & $\begin{array}{l}\text { poorly sorted, near symmetrical } \\
\text { skewness }\end{array}$ \\
\hline
\end{tabular}

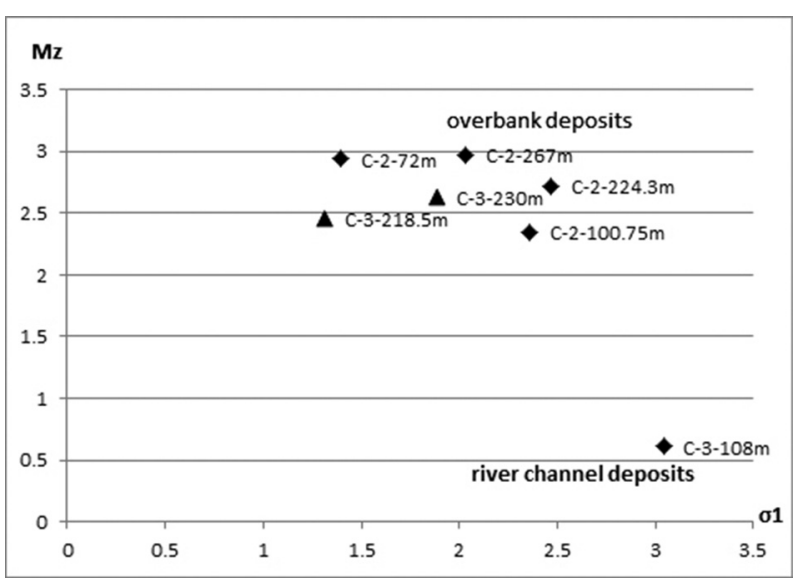

Fig. 5. Relationships of Folk and Ward (1957) textural parameters: mean grain diameter $(\mathrm{Mz})$ vs. standard deviation $(\sigma 1)$.

ki, Prestauroneis Bruder \& Medlin, Sellaphora Mereschkowsky, Cavinula D.G. Mann \& Stickle, Luticola D.G. Mann, Anemoeoneis Pfitzer, Stauroneis Ehrenberg, Pinnularia Ehrenberg, Caloneis Cleve, and Neidium Pfitzer. The most species-rich genera were Navicula Bory s.l. (14 taxa), Fragilaria Lyngbye s.l. (14), and Cymbella Ag. s.l. (13). Most of these species show single occurrence, but most representatives of the genus Fragilaria Lyngbye s.l. were determined as dominant and subdominant in the diatom associations (e.g., Staurosira construens Ehr., S. construens var. venter (Ehr.) Hamilton, Pseudostaurosira brevistriata (Grun.) Williams, Staurosirella martyi (Herib.) Morales \& Manoylov. The class Coscinodiscophyceae was represented by only three genera. The most abundant diatoms in the diatom associations were planktonic forms belonging to the genus Aulacoseira Thw.: A. ambi- gua (Grun.) Sim. and A. granulata (Ehr.) Sim. One very interesting form of the newly described genus Spicaticribra Johansen, Kociolek \& Lowe was subdominant only in profile C-2 (Figs 6-10).

The investigated flora consists almost entirely of recent species (91.4\%). Among the encountered taxa, emphasis was laid on the abundant centric species and Tetracyclus peragalli Herib., owing to their stratigraphic importance and evolutionary interest.

Aulacoseira ambigua was observed as dominant in almost all investigated samples (Table 2). Valve diameter varied strongly between 5-22 $\mu \mathrm{m}$; valve mantle length varied between 5-14.5 $\mu \mathrm{m}$; the areolae on the mantle are in spiral rows (12-18 in $10 \mu \mathrm{m})$. The areolae have circular form with deepseated vela. The linking spines have triangular shape with bicuspidated ends, and terminated each mantle costae. The Ringleiste is hollow. The rimoportulae are two per valve, without stalk. They are located on the Ringleiste. The external openings are large, visible in the light microscope (LM) (Fig. 6a, $c-k$ ).

Aulacoseira granulata was observed as dominant and subdominant in the diatom thanatocoenoses. Valve diameter ranges from $6.7 \mu \mathrm{m}$ to $22 \mu \mathrm{m}$, and valve mantle length is between of $3.8 \mu \mathrm{m}$ and $14.6 \mu \mathrm{m}$; the areolae on the mantle are in straight or spiral rows, $10-15$ in $10 \mu \mathrm{m}$. The areolae are coarse, round to square, covered by velar complex. The linking spines are notched triangular. The rimoportulae are found on the valve face/mantle junction, near the Ringleiste. Internally, the rimoportula has tightly curved stalks lying close to the mantle surface. The separating spines are conical, of varying length, from short to almost the length of the valve mantle (see Figs $6 b, 7 a-k$ ).

Recently, two new genera related to the old genus Thalassiosira Cl. were erected: Spicaticri- 


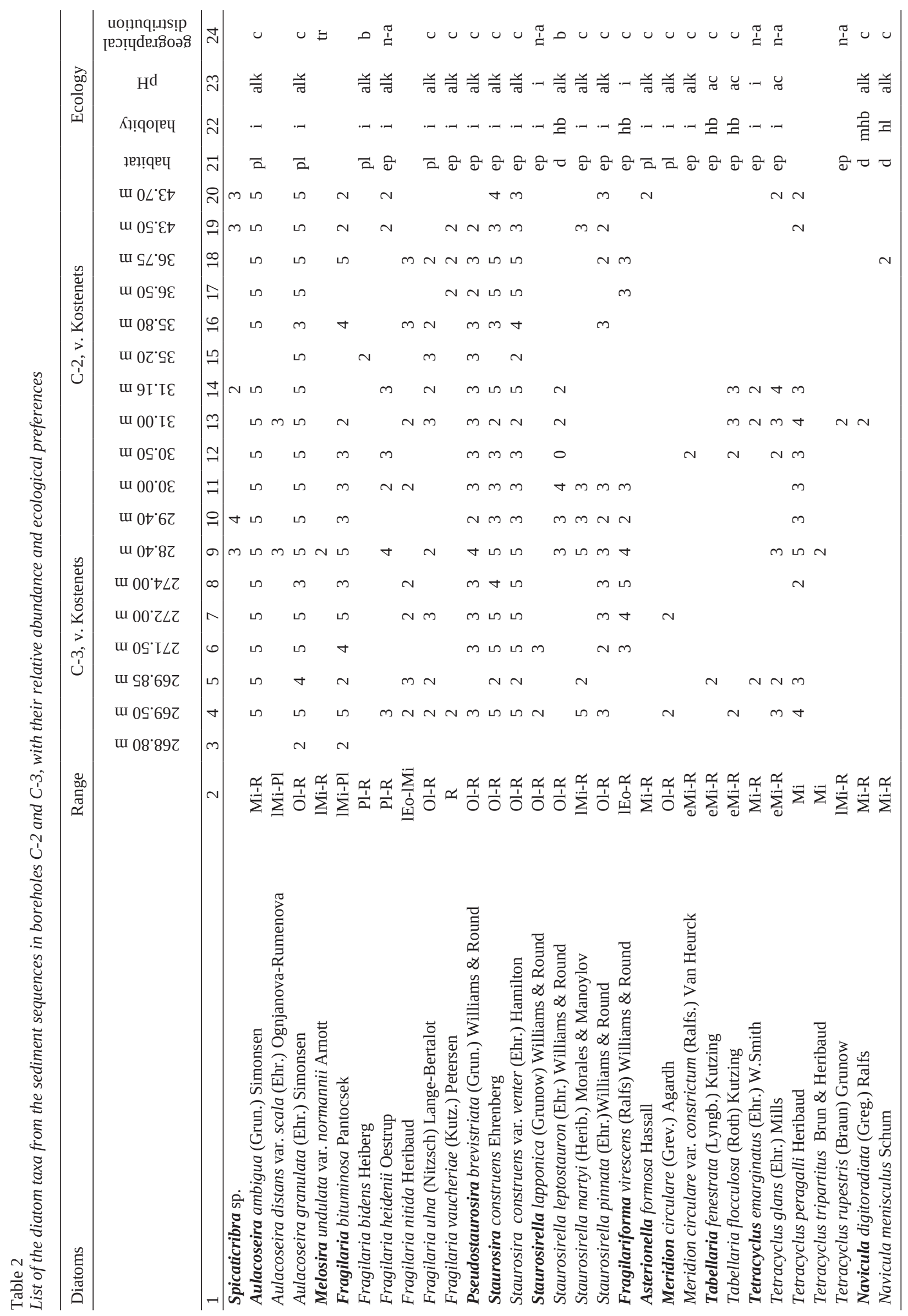




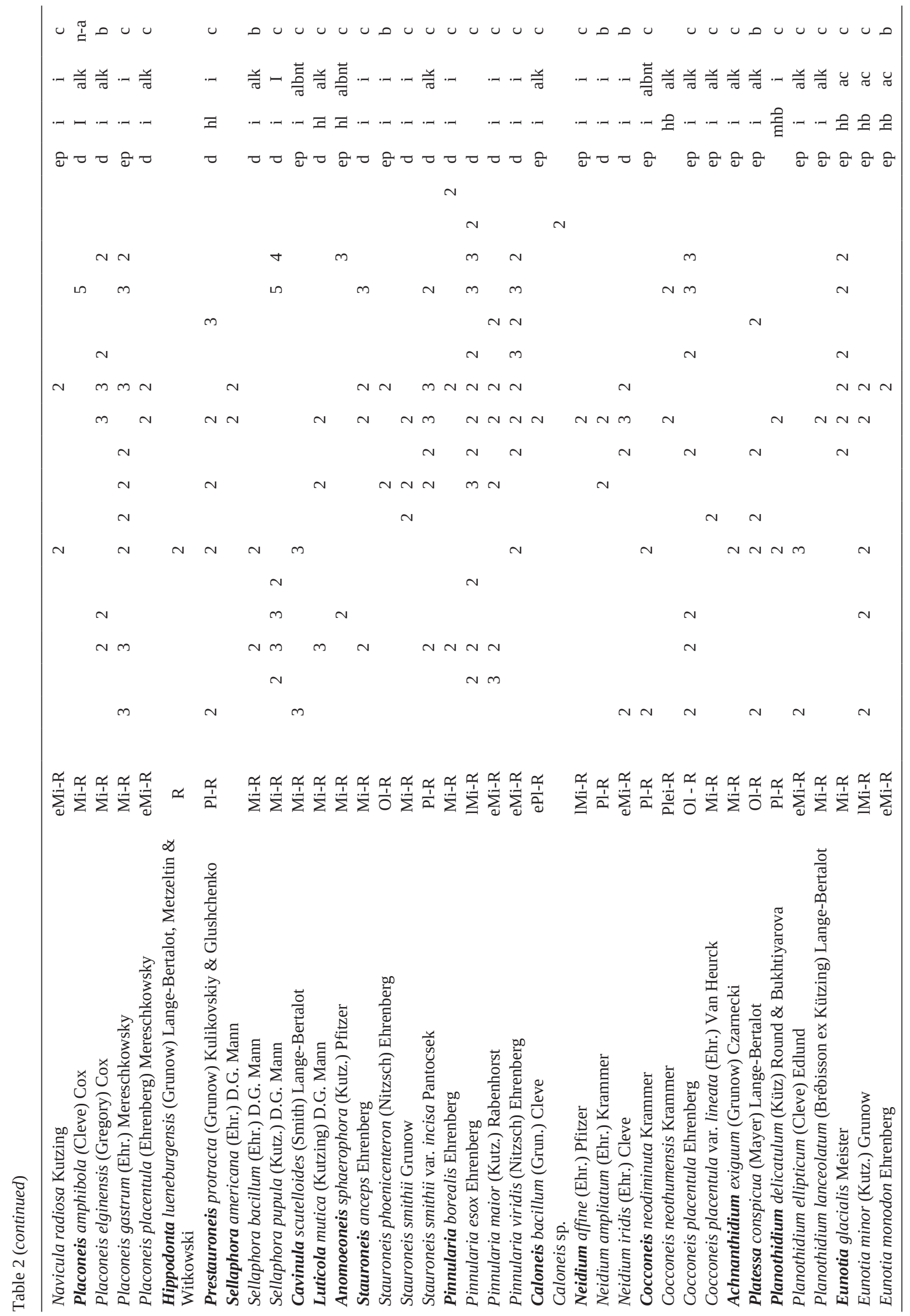




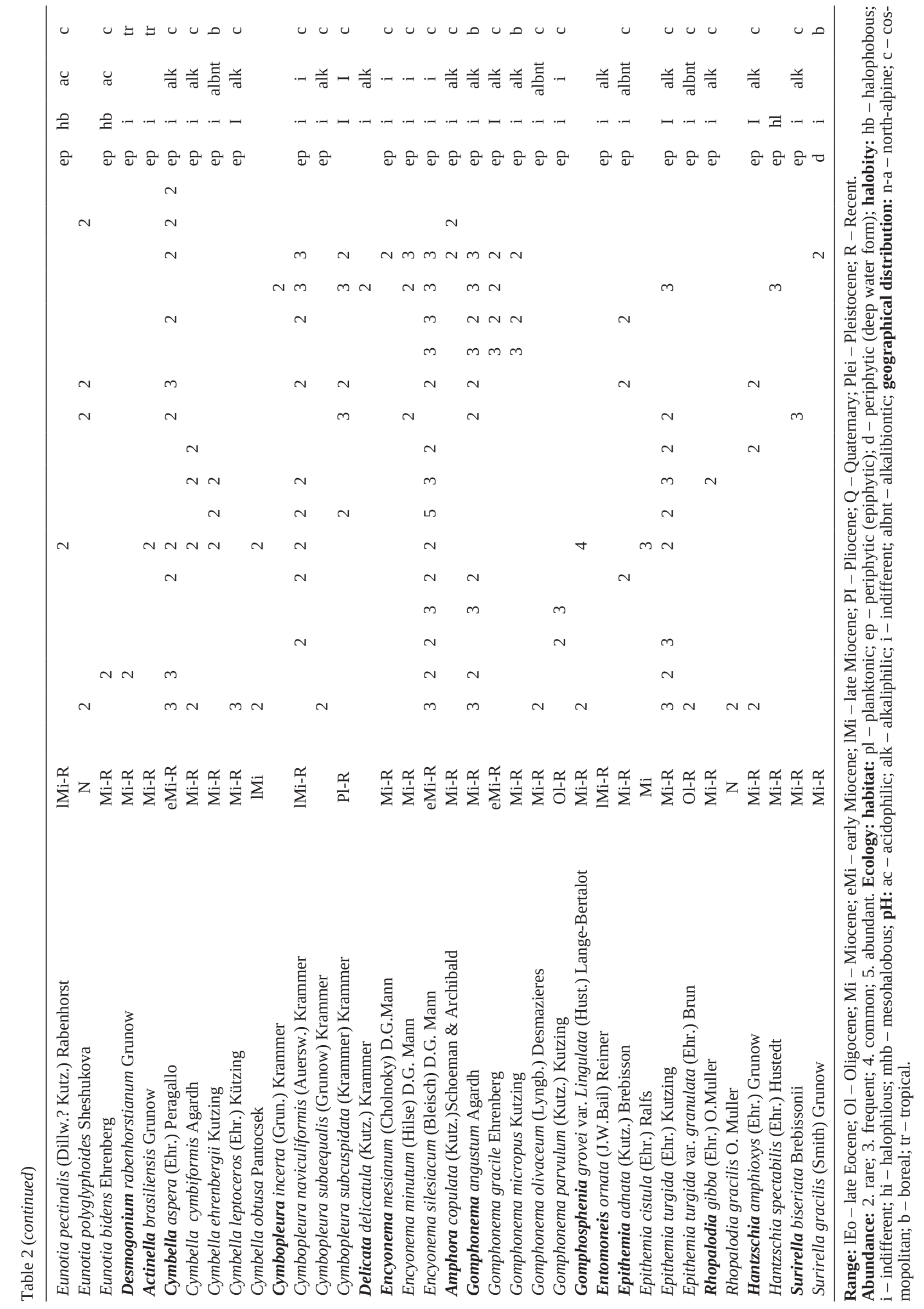



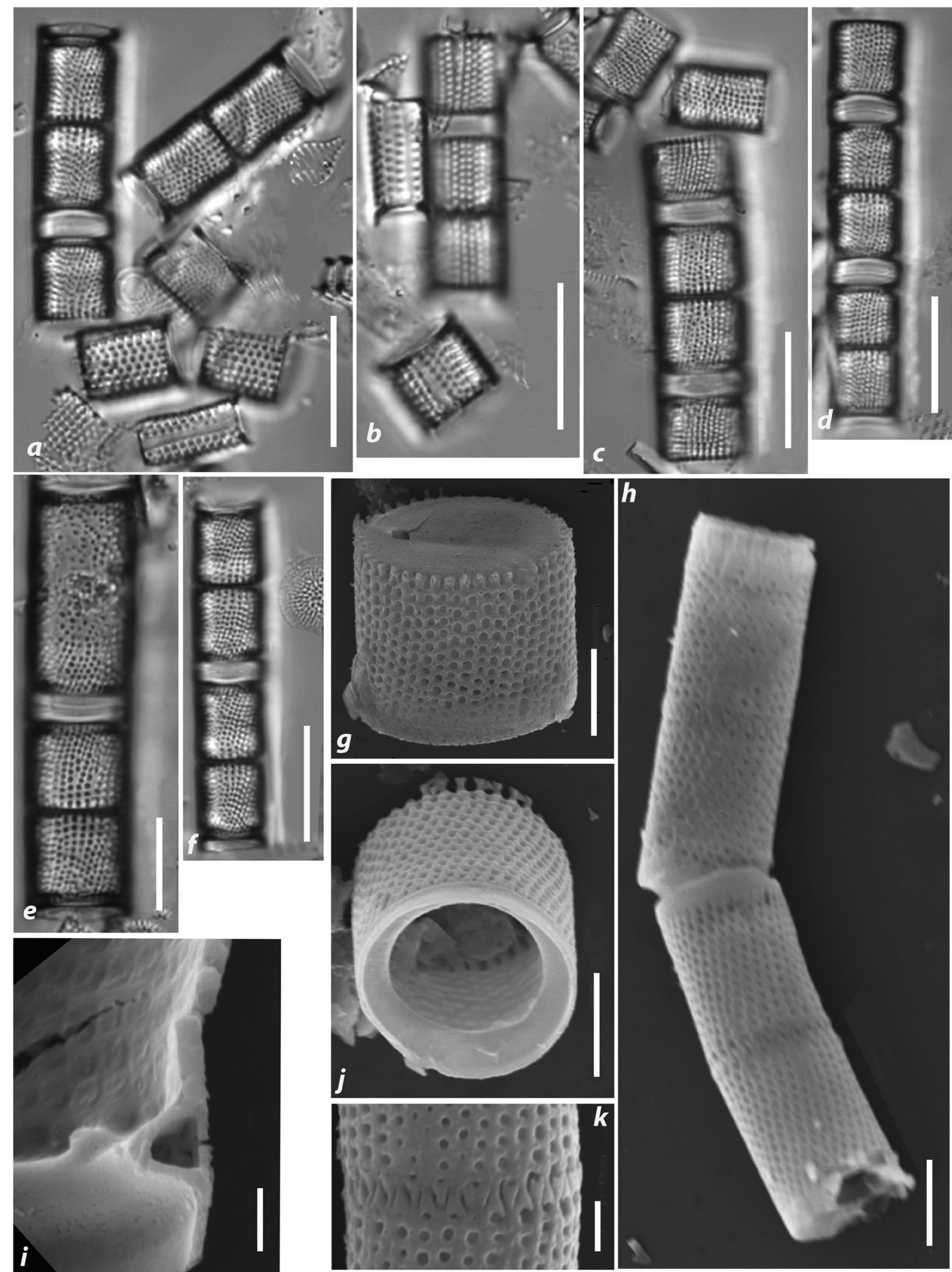

Fig. 6. a) The most abundant species in the studied profiles, belonging to the genus Aulacoseira Thw.: A. ambigua (Grun.) Sim. and A. granulata (Ehr.) Sim.; b) Aulacoseira granulata (Ehr.) Sim. - filaments with varying length of the separation spines; $c-f)$ Aulacoseira ambigua (Grun.) Sim., girdle view; Valve face view, focused to the coarse areolae; $g-h$ ) Aulacoseira ambigua (Grun.) Sim., girdle view of valves with different dimensions; i) Aulacoseira ambigua (Grun.) Sim., inner surface of the girdle, the Ringleist is hollow, the rimoportula without stalk; $j$ ) Aulacoseira ambigua (Grun.) Sim., the girdle view with the Ringleist; k) Aulacoseira ambigua (Grun.) Sim., detail of the linking spines - triangular form with bicuspidate ends. Scale bar $=10 \mu \mathrm{m}(a-f)$; $5 \mu \mathrm{m}(g-h, j) ; 1 \mu \mathrm{m}(i, k)$. 

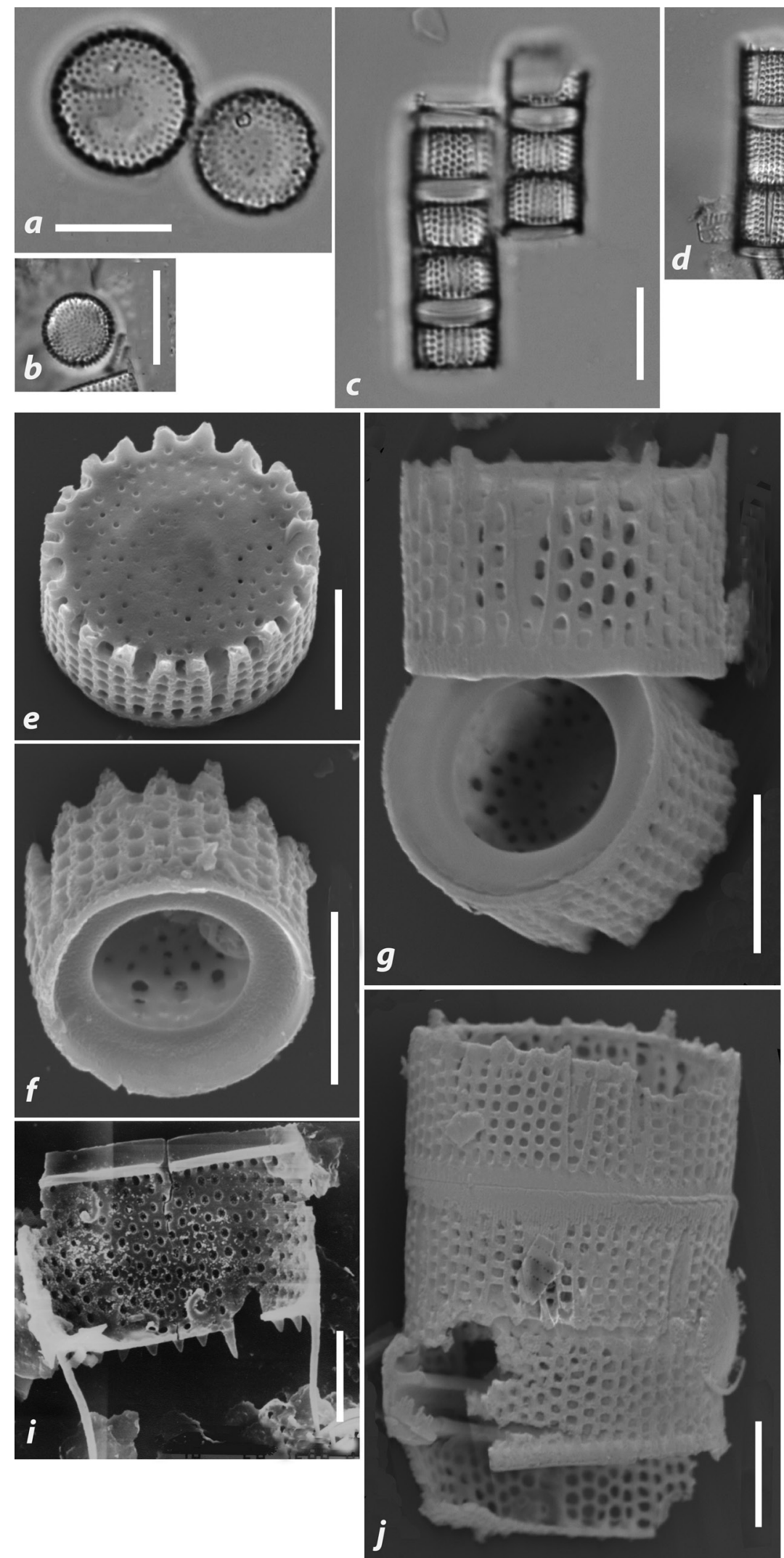

c
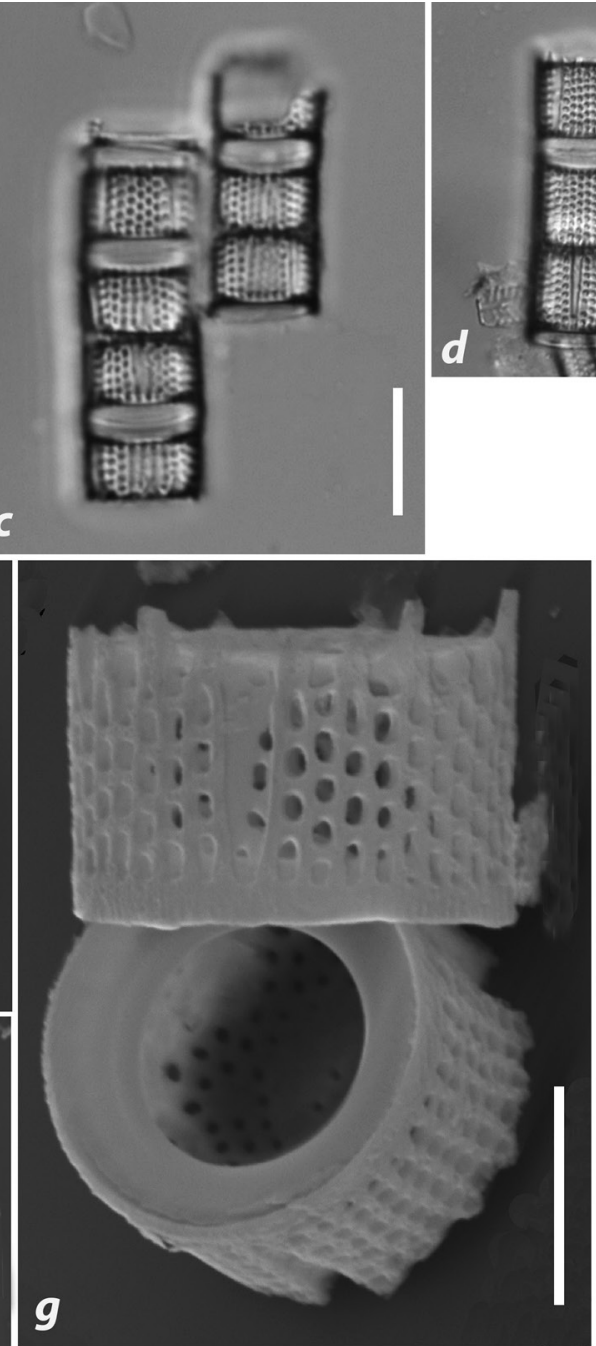
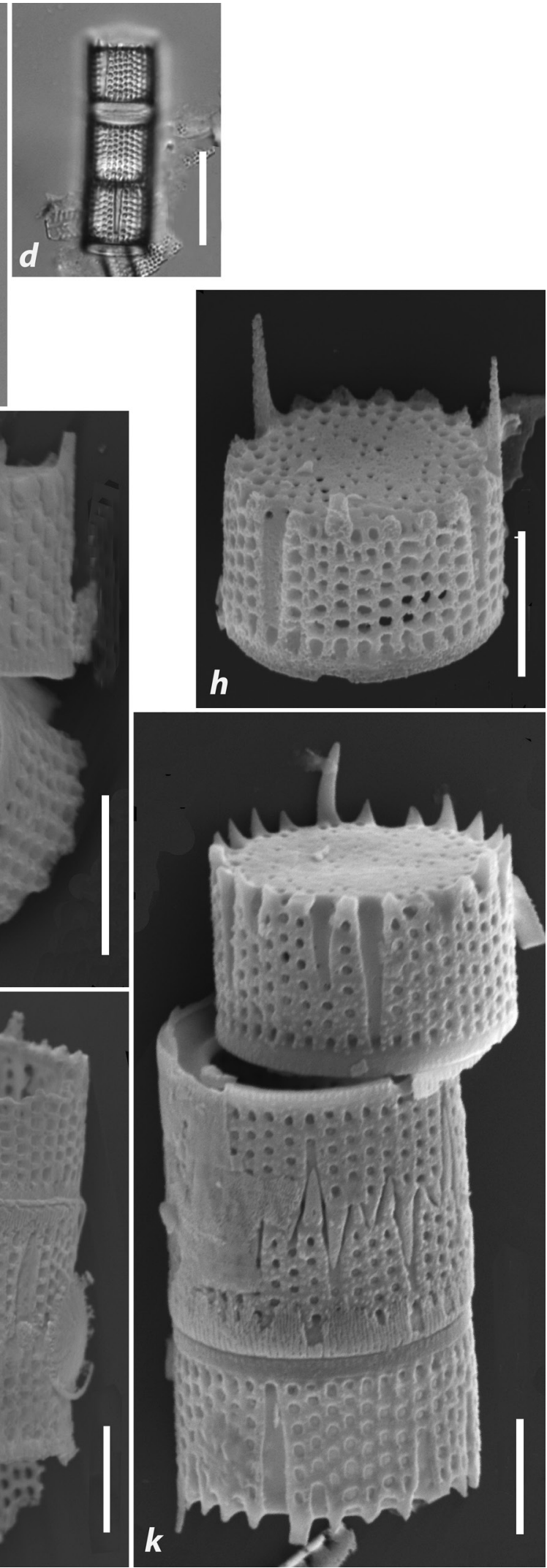

Fig. 7. Aulacoseira granulata (Ehr.) Sim. $a-b$ ) Valve view; $c-d$ ) Girdle view, see the narrow and long pointed separating spines; e) Valve view with irregular spaced coarser pori; $f-g$ ) Girdle view and the Ringleist; $h, j, k$ ) Girdle view of filaments with different length, note the long conical separating spines; $i$ ) Inner surface of the girdle with distinct curved rimoportulae. Scale bar $=10 \mu \mathrm{m}$ $(a-d) ; 5 \mu \mathrm{m}(e-k)$. 
bra Johansen, Kociolek \& Lowe and Conticribra Stachura-Suchoples \& Williams (Johansen et al., 2008; Stachura-Suchoples and Williams, 2009). In the inventory list of the extinct freshwater fossil diatoms, all these centric forms are referred to the genus Spicaticribra (Khursevich and Kociolek, 2012). This genus is distinguished by a combination of morphological features: loculate areolae with internal semi- to continous cribra, and external foraminae; absence of central fultoportulae; ring of marginal fultoportulae with 2-4 satellite pores; one or several rimoportulae located on the valve mantle. The determined specimens in the investigated profile C-2 are characterized by loculate areolae with continuous cribra and slightly undulated valve face. We identified these forms as Spicaticribra sp. Further studies on similar forms in the Gotse Delchev Basin (Bulgaria) and Pelagonia Basin (Northern Macedonia and Greece) will prove one new species for the Balkan area. Spicaticribra sp. was determined as rare and frequent only in profile C-2, but at level $29.40 \mathrm{~m}$ it is common. Valves are circular, with slightly transversally undulated valve face, with diameter between $6.5 \mu \mathrm{m}$ and $12 \mu \mathrm{m}$. Striae are radial, straight, some extending from the margin to the centre, others extending only partially to the centre, 15-18 in $10 \mu \mathrm{m}$. Areolae loculate are of larger size in the centre of the valve. Internally, they are covered by semi-continuous cribra, consisting of linearly arranged pores, areolae on the valve mantle being covered internally by continuous cribra. A rim defines the edge of the valve mantle. This rim is scored by narrow vertical lines and distinct external siliceous granules. Central fultoportulae are absent; there is a ring of marginal fultoportulae with three satellite pores. Single rimoportula replaces a marginal fultoportula (see Fig. 8a-k).

The genus Tetracyclus Ralfs is represented by five different species (Table 2). The most abundant and biostratigraphically significant is the extinct Tetracyclus peragalli Herib. According to Williams (2009), based on a study of the type material of Peragallo and Héribaud in the Diatom Collection of the Natural History Museum in London (BM), this is an extinct species, typical for the northern hemisphere. The valves have rostrate poles and a central constriction, length 17-24.4 $\mu \mathrm{m}$, width 9.5-14.6 $\mu \mathrm{m}$, and the robust transapical ribs are $3-5$ in $10 \mu \mathrm{m}$. The copulae are numerous, split and rostrate, having septa across the rostrate ends (Fig. 10a-h). Until now, this species has been reported from Miocene sediments in the Central Massif, France, and Lovelock, Nevada, USA (Williams, 2009), and China (Li and Qi, 1984). The latter identification is invalid, as the specimens described by Li and Qi (1984, Pl. 2,
Figs 3,6 ) do not have the rostrate poles or the typical central constriction.

\section{Notes on diatom thanatocoenoses}

The results of the diatom biostratigraphy were published previously (Ognjanova-Rumenova, 2004). Two diagrams synthesized the diatom analysis, which included all diatom species with relative abundance of 4-5 according to Schrader's scale in the least one sample. Three thanatocoenoses can be distinguished in the diatom successions, which are described below.

Within the ranges $43.70-36.50 \mathrm{~m}(\mathrm{C}-2)$ and 274.00-271.50 m (C-3), development of rich Aulacoseira Thw. flora was observed. The accompanying species are Fragilaria bituminosa Pant., Staurosira construens Ehr., S. construens var. venter (Ehr.) Hamilton, Placoneis amphibola (Cl.) Cox, and Sellaphora pupula (Kutz.) Mann.

From $35.80 \mathrm{~m}$ to $35.20 \mathrm{~m}(\mathrm{C}-2)$, the diatom flora is not so diverse; only species of Aulacoseira Thw. are abundant and most of the subdominants are rare or absent.

The third thanatocoenosis was observed in the sediments at levels 31.16-28.40 m (C-2) and 269.85-268.80 m (C-3). The genus Aulacoseira Thw. is again the most diverse in species at these levels, being widely developed: Tetracyclus glans (Ehr.) Mills, T. peragalli Herib., Staurosirella martyi (Herib.) Morales \& Manoylov, S. leptostauron (Ehr.) Williams \& Round, Fragilariforma virescens (Ralfs) Williams \& Round, and Fragilaria heidenii Østrup. At the uppermost level of C-2 (29.40$28.40 \mathrm{~m}$ ), high abundance of Spicaticribra sp., Gomphonema grovei var. lingulatum (Hustedt) Lange-Bert., and Encyonema silesiacum (Bleish.) D.G. Mann was noted.

Seven extinct species of stratigraphic significance were detected: Aulacoseira distans var. scala (Ehr.) Ognjan., Fragilaria bituminosa Pant., F. nitida Herib., Tetracyclus peragalli Herib., T. tripartitus Brun. \& Herib., Eunotia polyglyphoides Sheshuk., Cymbella obtusa Pant., Epithemia cistula (Ehr.) Ralfs, and Rhopalodia gracilis O. Mull. They can be considered as biostratigraphic markers for the upper Miocene (Pontian) (Temniskova-Topalova and Ognjanova-Rumenova, 1997; OgnjanovaRumenova, 2004).

\section{Ecological analysis of the diatom flora}

Of the total number of identified diatom taxa, 82.8\% were with known ecology. Palaeoenvironmental interpretation is based on the major trends in relative 

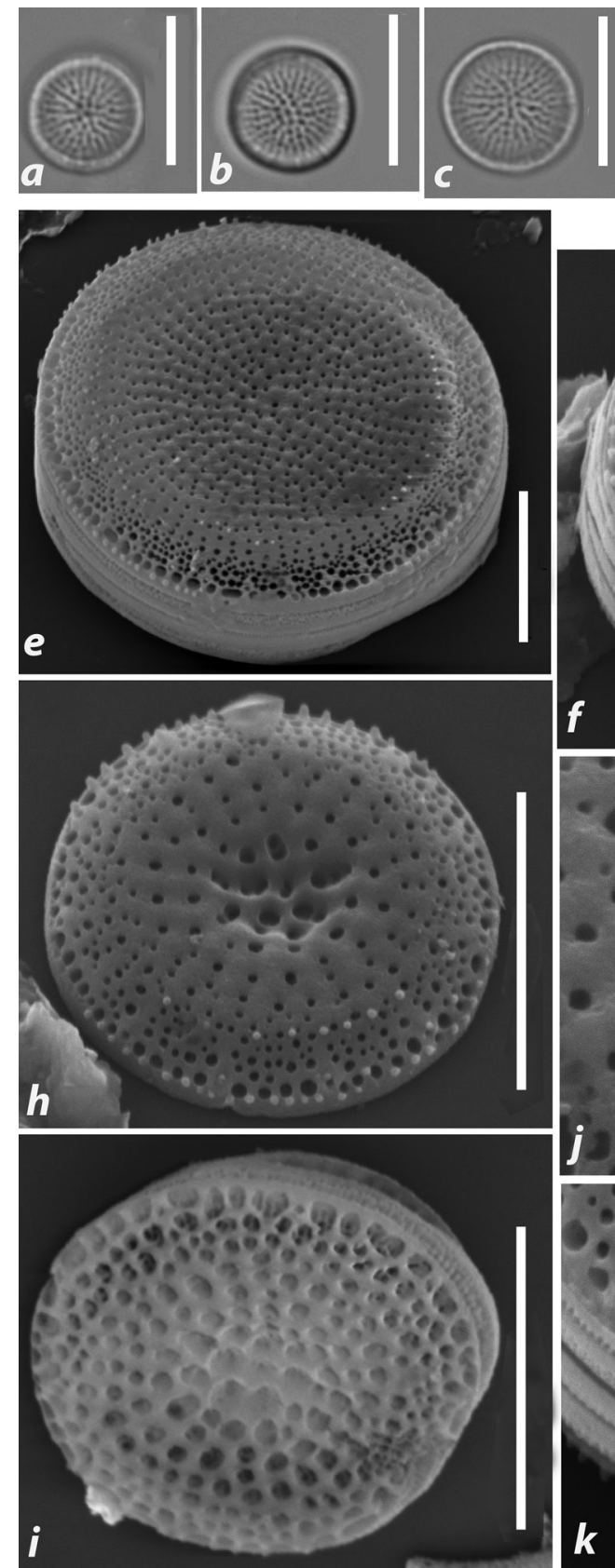
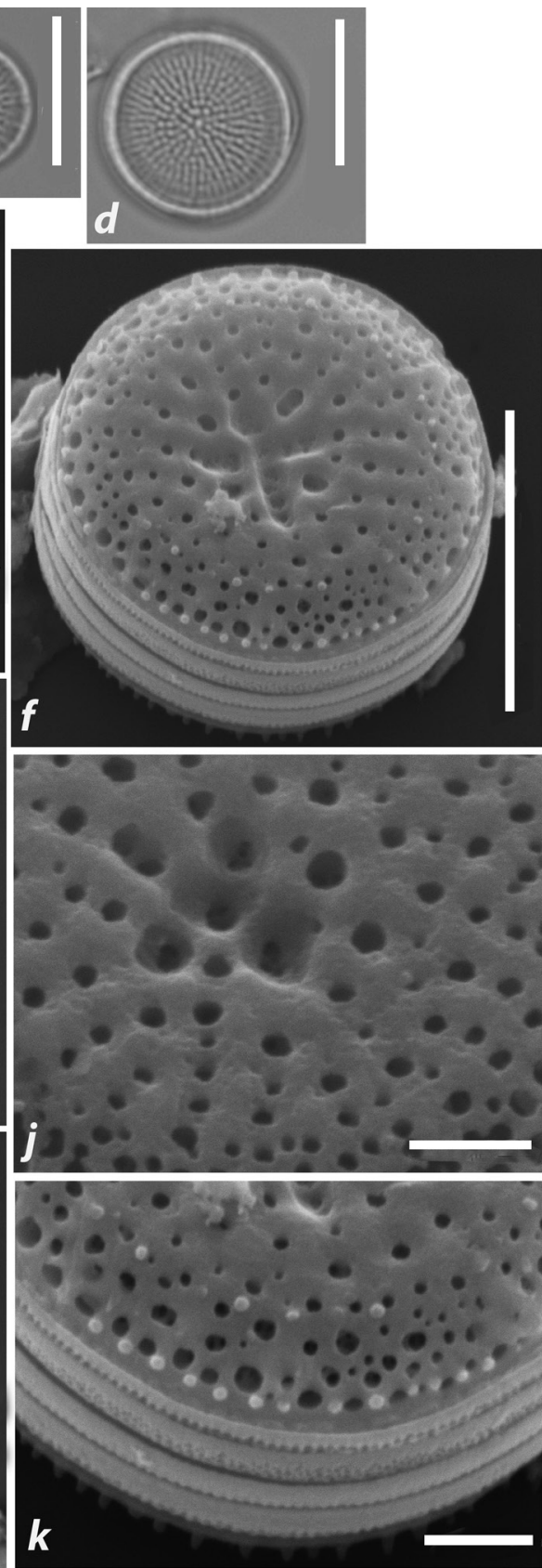

$m$
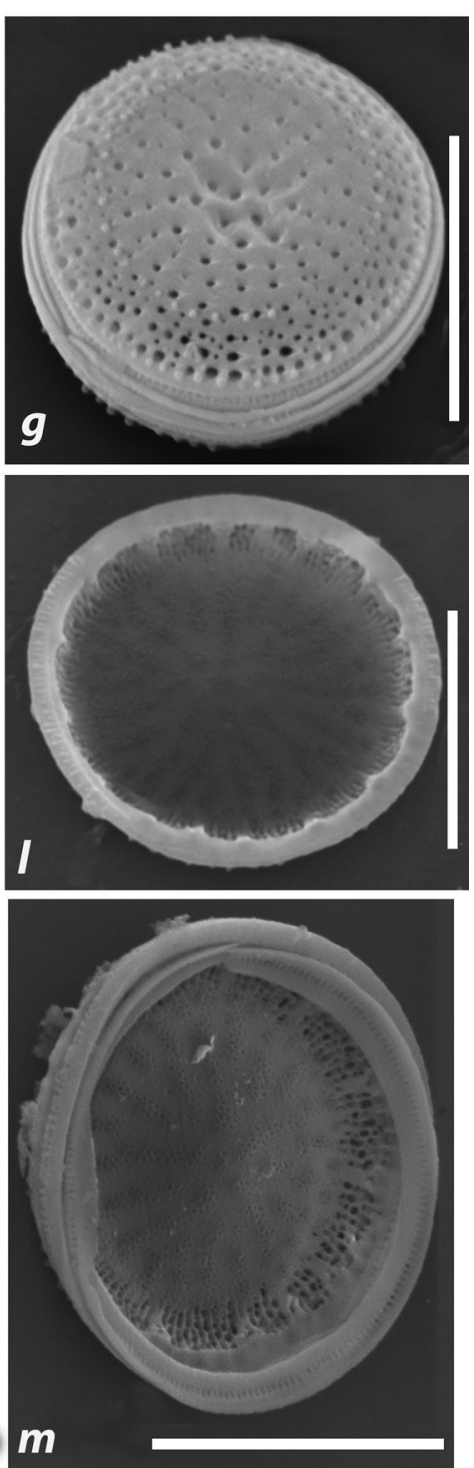

Fig. 8. Spicaticribra sp. $a-d$ ) Valve view, size increased series; $e-i$ ) External valve view, note the different stages of dissolution of the surfaces, and different extending of the striae in the central area; $j$ ) Detail: areolae loculate with larger size in the central part of the valve; $k$ ) Detail: the edge of the valve mantle with distinct external siliceous granules; $l-m$ ) Internal valve view, note the radial rows of pores, the position of the marginal fultoportulae, as well as - the single rimoportula. Scale bar $=10 \mu \mathrm{m}(a-d) ; 5 \mu \mathrm{m}$ $(e-i, l-m) ; 1 \mu \mathrm{m}(j, k)$.

abundance of ecological diatom groups (related to habitat, active reaction of the water, halobity, temperature, etc.), as well as on the percentage ratio of diatom frustules/chrysophycean stomatocysts. The results of the ecological analyses are presented in Figs 11, 12.
Biogeographical information was available for 86 (82\% of the total) taxa. The diatom flora was mainly composed of cosmopolitan species (74.4\%), followed by boreal species (15.1\%), and a lower percentage of north-alpine forms (7\%). There were a few tropical species (3.5\%): Melosira undulata var. 


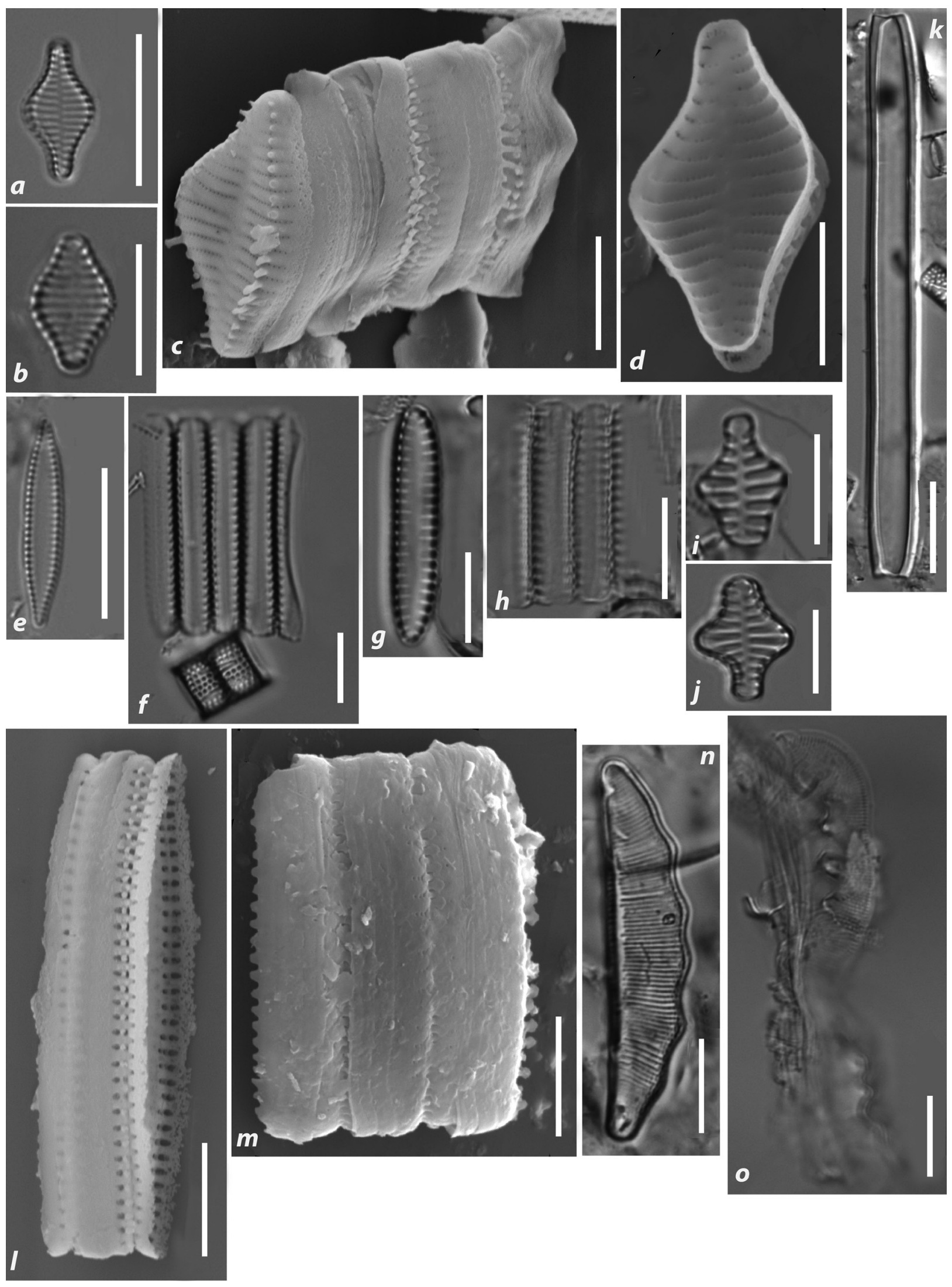

Fig. 9. $a, c, d$ ) Staurosira construens Ehrenberg; b) Staurosira construens var. venter (Ehr.) Hamilton; e, l) Pseudostaurosira brevistriata (Grun.) Williams \& Round; $f-h, m)$ Fragilaria bituminosa Pantocsek; $i-j$ ) Staurosirella leptostauron (Ehr.) Williams \& Round var. indet.; k) Fragilaria nitida Heribaud; $n$ ) Eunotia polyglyphoides Sheshukova; o) Entomoneis ornata (J.W. Bail) Reimer. Scale bar $=10 \mu \mathrm{m}(a, b, e-k, n, o) ; 5 \mu \mathrm{m}(c, d, l, m)$. 

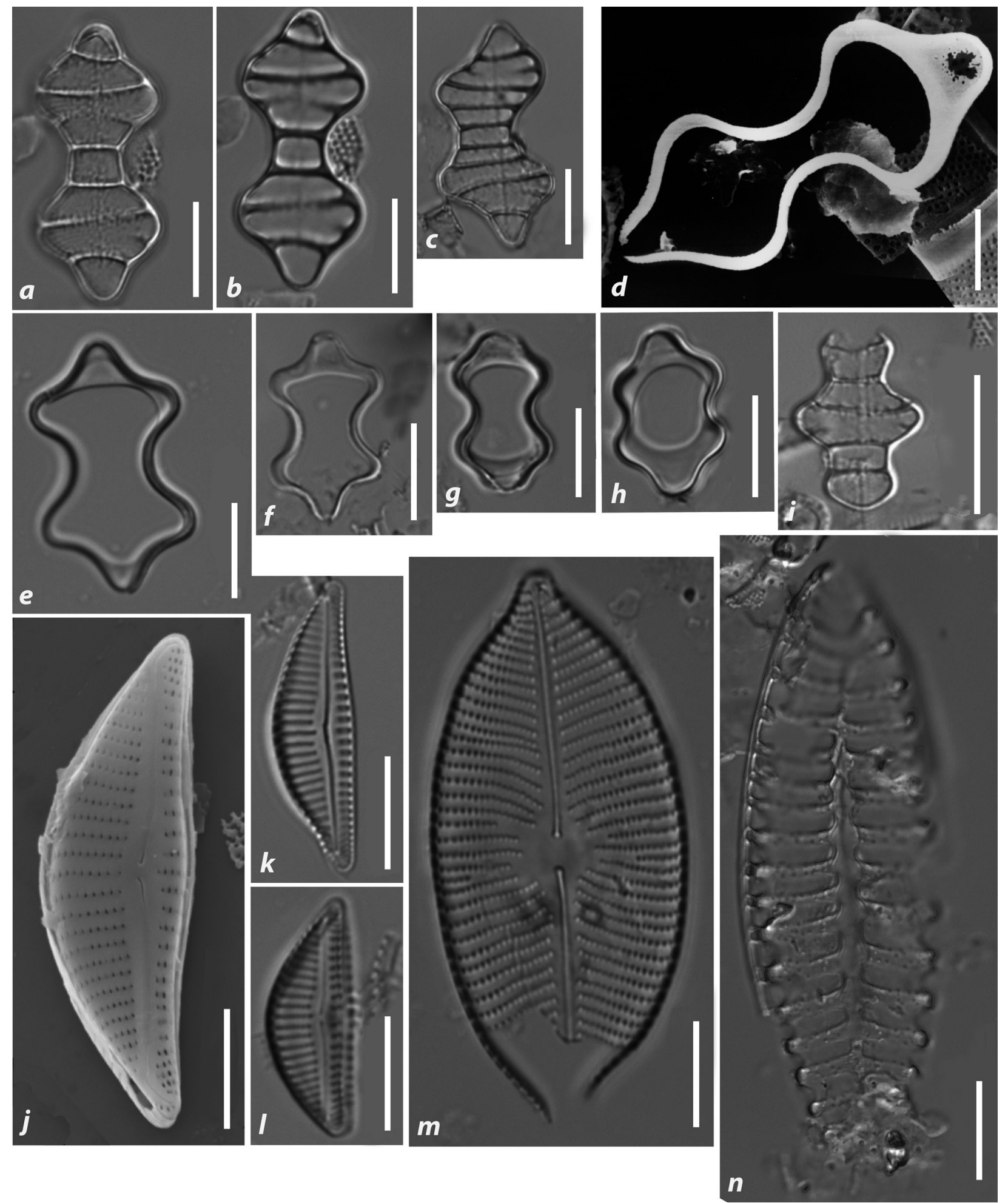

Fig. 10. $a-h)$ Tetracyclus peragalli Heribaud ( $a-c$, Valve face; $d$, Single element from cingulum; $e-h$, Copulae numerous, split and rostrate, provided with septa across the rostrate ends); i) Tetracyclus glans (Ehr.) Mills; j-l) Encyonema silesiacum (Bleisch) Mann; m) Cymbopleura sp.; $n)$ Surirella biseriata Brebisson. Scale bar $=10 \mu \mathrm{m}(a-c, e-i, k-n) ; 5 \mu \mathrm{m}(d, j)$. 


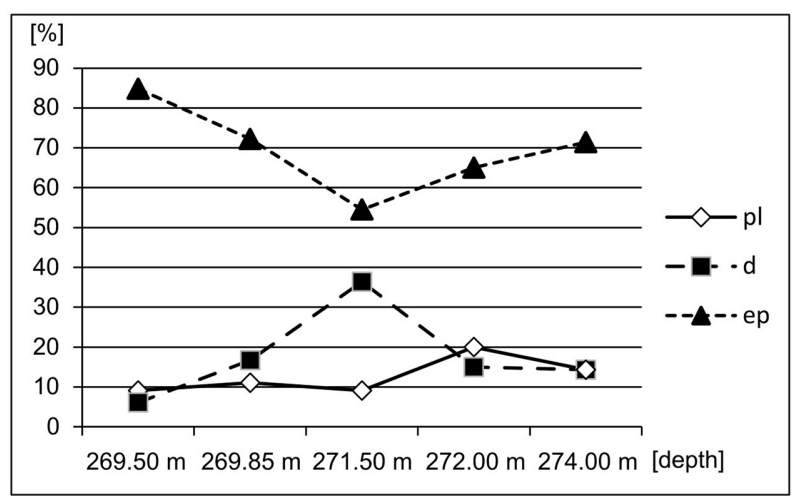

C-3 Kostenets, habitat

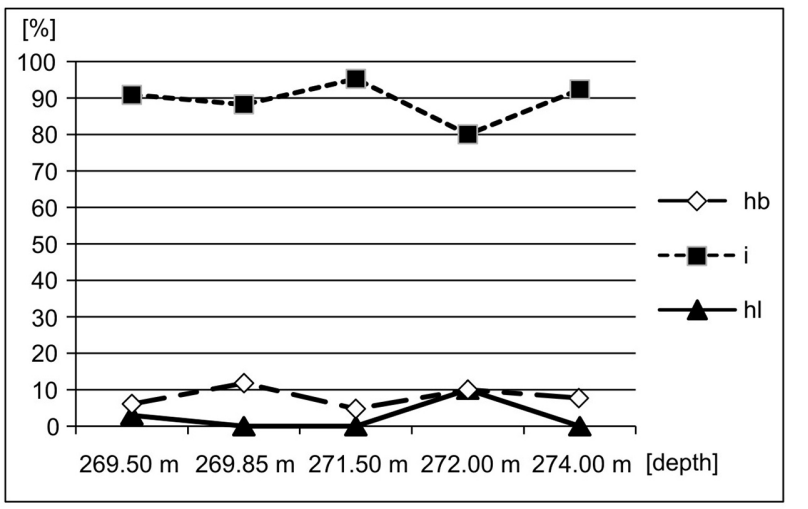

C-3 Kostenets, halobity

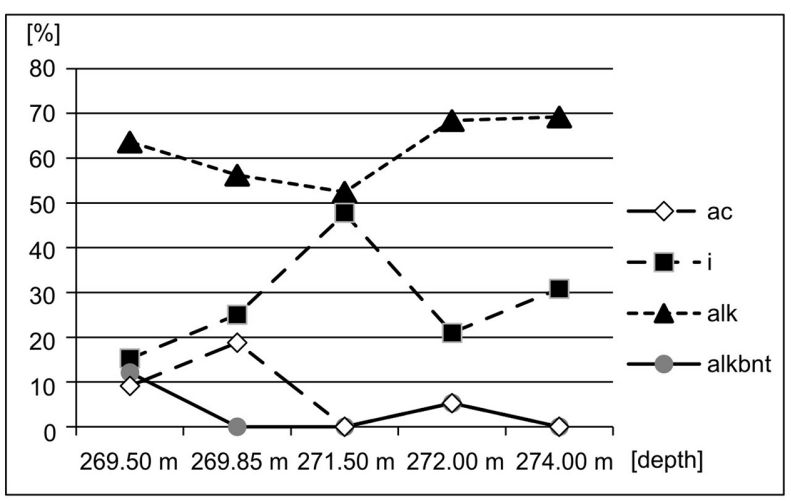

C-3 Kostenets, $\mathrm{pH}$

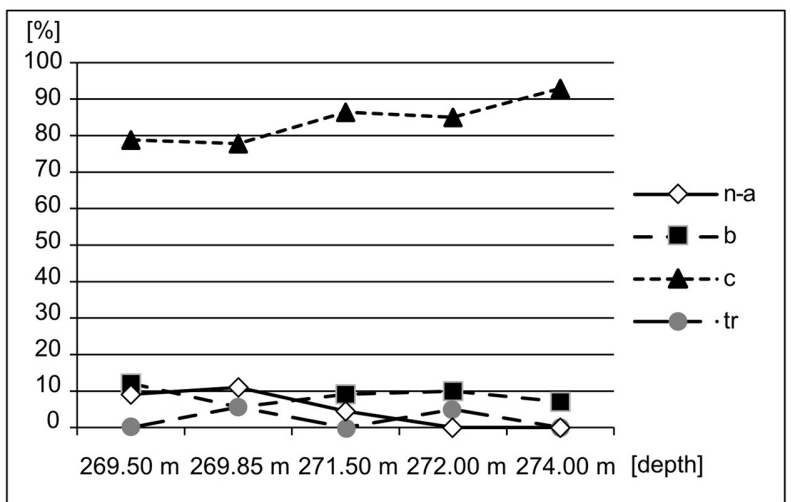

C-3 Kostenets, geographical distribution

Fig. 11. Percentage diagrams of the different ecological diatom groups in depth of borehole C-2, Kostenets Basin (for abbreviations in this and the next following diagrams, see the legend of Table 2).

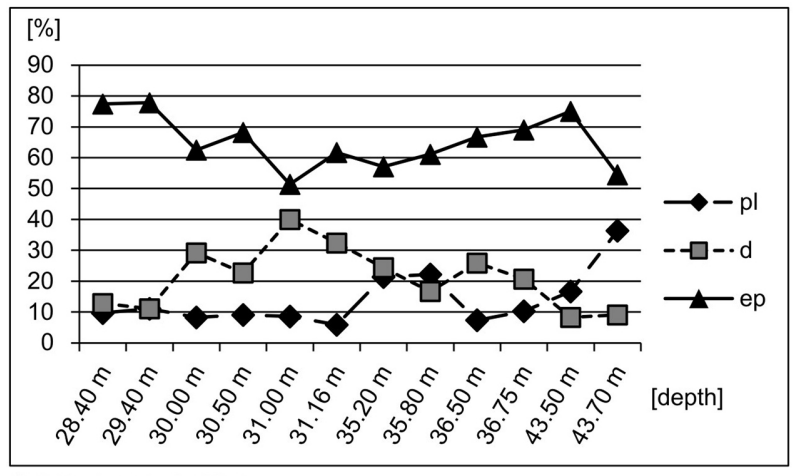

C-2 Kostenets, habitat

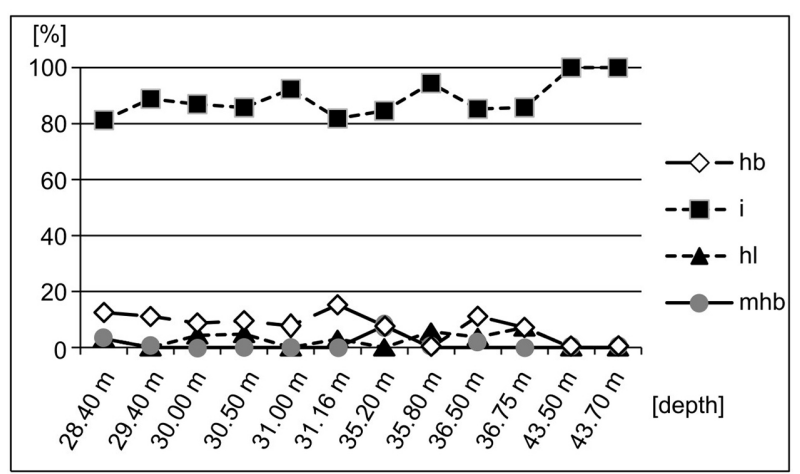

C-2 Kostenets, halobity

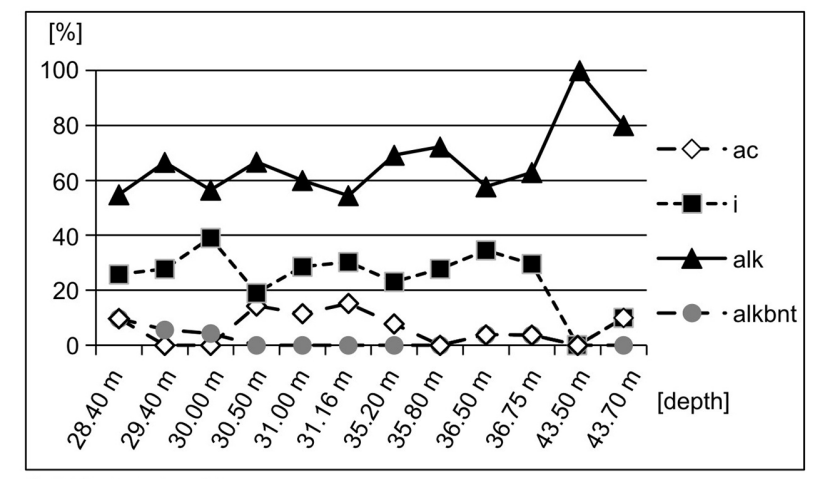

\section{C-2 Kostenets, $\mathrm{pH}$}

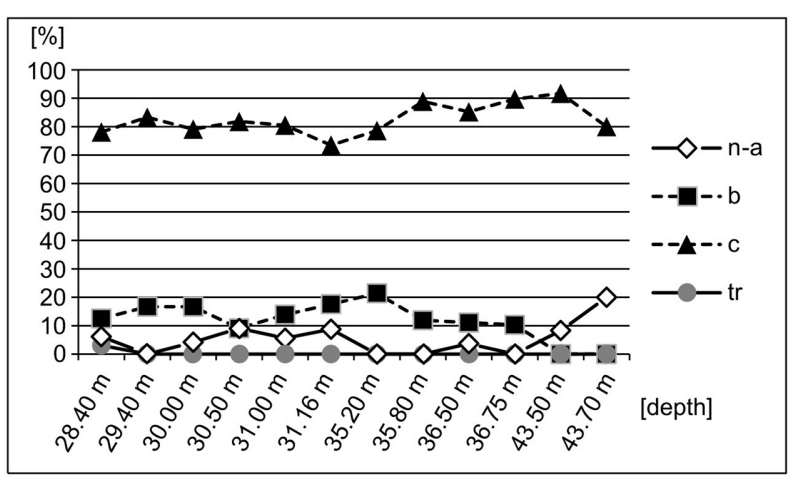

C-2 Kostenets, geographical distribution

Fig. 12. Percentage diagrams of the different ecological diatom groups in depth of borehole C-3, Kostenets Basin. 
normannii Arnott, Desmogonium rabenhorstianum Grun., and Actinella brasiliensis Grun., with very rare occurrences in both profiles (Figs 11, 12).

In regards to general and specific habitats, periphytic species dominated the flora. Planktonic species accounted only for $7.1 \%$, but they were dominant and subdominant upwards in the sequences [i.e., Aulacoseira ambigua (Grun.) Sim. and A. granulata (Eh.) Sim]. The high proportion of filaments with ending spines in Aulacoseira granulata in the uppermost levels of the investigated profiles may indicate that they alternated between flood and drought in the palaeoenvironment (Wang et al., 2017). That was confirmed by the occurrence of the rheophylic representatives belonging to the genus Tetracyclus Ralfs at the same levels.

Grouping of diatoms according to their $\mathrm{pH}-$ preferences showed that alkaliphilous (54.2\%) and $\mathrm{pH}$-indifferent (27.7\%) were clearly predominant. Only $9.6 \%$ acidophilic species were present, most of them belonging to the genera Tabellaria Ehr., Tetracyclus Ralfs, and Eunotia Ehr. Their percentages increased in depth in the interval 30.50$31.16 \mathrm{~m}$ (borehole C-2) and at level $269.85 \mathrm{~m}$ (borehole C-3) (Figs 11, 12).

The diatom flora consisted mainly of oligohalobous species, with prevalence of indifferent species (80.5\%). Most of the species of the halophobous (11.5\%) and halophilous groups (5.7\%) had lower relative abundance in the diatom thanatocoenoses. A small percentage of mesohalobous forms (2.3\%) occurred in the investigated sequence of borehole C-2 (Fig. 11).

\section{Relative proportions of diatom frustules and chrysophycean stomatocysts}

Tracing the ratio of diatom frustules/chrysophycean stomatocysts in the studied profiles C-2 and C-3, only one peak in the development of the chrysophyceans was determined: in C-3, at depth of $269.85 \mathrm{~m}$. Chrysophyceans were dominant (51\%), and only Aulacoseira ambigua (Grun.) Sim. was established by the same quantity. At this level, a change in the lithology was also determined.

\section{PALAEOENVIRONMENTAL INTERPRETATION}

During the late Miocene-early Pliocene (MaeotianDacian), the Kostenets Basin was a large fluvial system with local developments of alluvial fans, swamps and shallow lake areas. The Neogene sedimentary succession started during the Maeotian with deposition of alluvial sediments assigned to the Beli
Dol Formation. The alternation of sand, silty and clayey sands with gravels and rare conglomerates in the lower part of borehole C-2 represents alluvial deposits of river channel and overbank. Upwards, deposits become finer and clayey sediments start dominating. The presence of charred plant detritus and abundance of dispersed organic matter among the clays indicate environmental transition from alluvial to paludal at about the 131-m level, which changes into lacustrine farther upwards.

The change of environment that resulted in the deposition of the diatom-bearing sediments is related to the Gabrovitsa Formation. The diatombearing sediments in the central part of the basin were formed during the late Pontian. The relative abundance of planktonic and littoral forms provides rough information on the types of macrohabitats recorded in our samples. Few species are planktonic, but their frequency in depth may reach more than $90 \%$ of the diatom population. The genus Aulacoseira Thw. is by far the most important. The most abundant species, A. ambigua (Grun.) Sim. and A. granulata (Ehr.) Sim., proved the natural eutrophication in the palaeolake during the late Pontian. The studied sediments are also characterized by an assemblage with Fragilariforma virescens (Ralfs) William \& Round, Staurosirella leptostauron (Ehr.) William \& Round, and S. martyi (Herib.) Morales $\&$ Manoylov as subdominants. This assemblage reflects the occurrence of a shallow water body with low salinity (0.2-0.3\%o) and slight alkalinity. The water body was colonized by macrophytes, proved by the occurrence of epiphytic taxa [especially Encyonema silesiacum (Bleisch) Mann, Cymbopleura navicuiformis (Auersw.) Krammer, Gomphonema angustum Ag., and Epithemia turgida (Ehr.) Kütz]. The high proportion of filaments with ending spines in Aulacoseira granulata in the uppermost levels of the investigated profiles indicates the high turbulence of the water (Wang et al., 2017). That was confirmed by the occurrence of rheophylic representatives belonging to the genus Tetracyclus Ralfs at the same levels. At this level, finely laminated diatomaceous clays disappear and are replaced by massive-bedded silty and sandy clays with quartz grains and mica flakes, which confirm the change of the environment.

The overlying coarse sediments consist of conglomerates, sands, sandy clays and clayey siltstones and were deposited in alluvial environment again, as river channel and overbank. They are referred to the Dolno Pole Formation (Vatsev and Jordanov, 1996). This marks the end of the lacustrine-paludal stage of the basinal evolution and the beginning of a new fluvial cycle. 


\section{CONCLUDING REMARKS}

This paper presents the first comprehensive lithological and biostratigraphic study on diatoms and chrysophycean stomatocysts from lacustrine deposits in the central zone of the Kostenets Neogene Basin.

The total number of the diatom taxa recorded in the diatom-bearing samples from the surveyed boreholes is 105 . The dominant complex of the investigated diatom flora consists of two recent Aulacoseira representatives: A. ambigua (Grun.) Sim. and A. granulata (Ehr.) Sim. A diverse taxonomical composition is reported for the genus Tetracyclus Ralfs. Similar species of this genus have been identified from lacustrine sediments of the Central Massif, France.

The flora comprises some typical species for the late Miocene (Pontian): Aulacoseira distans var. scala (Ehr.) Ognjan., Fragilaria bituminosa Pant., F. nitida Herib., Tetracyclus peragalli Herib., T. tripartitus Brun. \& Herib., Eunotia polyglyphoides Sheshuk., Cymbella obtusa Pant., Epithemia cistula (Ehr.) Ralfs, and Rhopalodia gracilis O.Mull.

The results of the comprehensive lithological and analyses presented herein allow a reconstruction of the palaeoecological conditions of the Kostenets Neogene Basin at the end of the Miocene and the beginning of the Pliocene.

\section{Acknowledgements}

The authors are thankful to our reviewers Dr Elena Koleva, Dr David Williams, and Dr Zlatko Levkov for their valuable and constructive comments. This research was supported by the Synthesis awards DETAF-5004, Freie Universität Berlin, http://www. synthesys.info/) to Nadja Ognjanova-Rumenova.

\section{REFERENCES}

Anonymous. 1975. Proposal for standardization of diatom morphology and diagnoses. Nova Hedwigia 53, 323-354.

Bonchev, G. 1906. Petrographic sketch of the High Balkan, Sredna Gora and Ihtiman Sredna Gora Mountain (M 1:300,000). Volume of Folklore and Naturalist Works 22, 1906-1907 (in Bulgarian).

Bonchev, G. 1917. Sedimentary rocks in Bulgaria. Comptes Rendus de l'Académie bulgare des Sciences 7, 108 pp.

Dimitrova, R., Katskov, N. 1990. Geological map of the Republic of Bulgaria in scale 1:100 000, Velingrad map sheet. Committee of Geology, Company for Geophysical Surveys and Geological Mapping, Sofia.

Folk, R.L. 1954. The distinction between grain size and mineral composition in sedimentary rock nomenclature. Journal of Geology 62 (4), 344-359.

Folk, R.L., Ward, W.C. 1957. Brazos River bar: A study in the significance of grain-size parameters. Journal of Sedimentary Petrology 27 (1), 3-26.

Glezer, S., Makarova, I., Moisseeva, A., Nikolaev, V. 1988. The diatoms of the USSR. Fossil and recent. Nauka, Saint Petersburg, 115 pp. (in Russian).

Grânčarov, M. 1961. Notes on the geology of the KostenecSestrimo area with special reference to certain tectonic problems. Review of the Bulgarian Geological Society 22 (1), 1-16 (in Bulgarian, with English abstract).

Hasle, G., Fryxell, G. 1970. Diatoms: Cleaning and mounting for light and electron microscopy. Transactions of American Microscopic Society 89 (4), 469-474.

Johansen, J., Kociolek, P., Lowe, R. 2008. Spicaticribra kingstonii, gen. nov. et sp. nov. (Thalassiosirales, Bacillariophyta) from Great Smoky Mountains National Park, U.S.A. Diatom Research 23, 367-375.
Khursevich, G., Kociolek, J.P. 2012. A preliminary, worldwide inventory of the extinct, freshwater fossil diatoms from the orders Thalassiosirales, Stephanodiscales, Paraliales, Aulacoseirales, Melosirales, Coscinodiscales, and Biddulphiales. Nova Hedwigia 141, 315-364.

Kojumdgieva, E., Nikolov, I., Mein, P. 1984. Les associations de grands mammifères du Miocène Supérieur en Bulgarie et leur corrélation avec l'échelle régionale de la Paratéthys. Comptes Rendus de l'Académie bulgare des Sciences 37 (3), 341-343.

Konjaroff, G. 1932. Die Braunkohlen Bulgariens. Pernik, 303 pp (in Bulgarian).

Li, J., Qi, Y. 1984. Neogene Diatom Assemblages in China. Proceedings of the $8^{\text {th }}$ International Diatom Symposium, Koeltz Scientific Books, Koenigstein, 699-711.

Lowe, R. 1974. Environmental requirements and pollution tolerance of freshwater diatoms. Bowling Great State University, Cincinnati, Ohio, 334 pp.

Ludwikowska-Kędzia, M. 2000. Ewolucja środkowego odcinka doliny rzeki Bełnianki w późnym glacjale i holocenie. Dialog Press, Warszawa, 188 pp.

Mycielska-Dowgiałło, E. 2007. Metody badań cech teksturalnych osadów klastycznych i wartość interpretacyjna wyników. In: Mycielska-Dowgiałło, E., Rutkowski, J. (Eds), Badania cech teksturalnych osadów czwartorzędowych $i$ wybrane metody oznaczania ich wieku. Przegląd Naukowy. Inżynieria i Kształtowanie Środowiska, 95-180.

Mycielska-Dowgiałło, E., Ludwikowska-Kędzia, M. 2011. Alternative interpretations of grain-size data from Quaternary deposits. Geologos 17 (4), 189-203.

Naydenov, K., Sarov, S., Voynova, E., Zhelezarski, T., Georgieva, I., Nikolov, D., Petrov, N., Markov, N., Marinova, R. 
2008. Geological map of the Republic of Bulgaria in scale 1:50 000, Kostenets map sheet. Committee of Geology, Company for Geophysical Surveys and Geological Mapping, Sofia.

Ognjanova-Rumenova, N. 1991. Neogene diatoms from sediments of Sofia Valley and their stratigraphic significance. $\mathrm{PhD}$ thesis, Geological Institute, Bulgarian Academy of Sciences, Sofia, 330 pp. (in Bulgarian, unpublished).

Ognjanova-Rumenova, N. 2004. Diatom biostratigraphy of Gabrovitsa Formation, Kostenets basin, South Bulgaria. Bulgarian Geological Society, Annual Scientific Conference "Geology 2004”, 63-64.

Ognjanova-Rumenova, N., Yaneva, M. 2003. Palaeoecological development of Kostenets basin, South Bulgaria, during the Late Miocene. In: Workshop "Palaeolimnology of the Serbian Neogene" 7-11 July 2003, Abstracts, 10-12.

Ross, R., Cox, E., Karayeva, N., Mann, D., Paddock, T., Simonsen, R., Sims, P. 1979. An amended terminology for the siliceous component of the diatom cell. Nova Hedwigia 64, 513-533.

Round, F., Crawford, R., Mann, D. 1990. The Diatoms. Biology \& Morphology of the genera. Cambridge University Press, Cambridge, $747 \mathrm{pp}$.

Schrader, H.-J. 1973. Proposal for a standardized method of cleaning diatom-bearing deep sea and land-exposed marine sediments. Nova Hedwigia 45, 403-409.

Smol, J. 1985. The ratio of diatom frustules to chrysophycean statospores: a useful palaeolimnological index. Hydrobiologia 123 (2), 199-204.

Stachura-Suchoples, K.,Williams, D. 2009. Description of Conticribra tricircularis, a new genus and species of Thalassiosirales, with a discussion on its relationship to other contin- uous cribra species of Thalassiosira Cleve (Bacillariophyta) and its freshwater origin. European Journal of Phycology 44, 477-486.

Temniskova-Topalova, D., Ognjanova-Rumenova, N. 1997. Description, comparison and biostratigraphy of the nonmarine Neogene diatom floras from Southern Bulgaria. Geologica Balcanica 27 (1-2), 57-81.

Vâlkova, N., Spiridonov, H. 1979. The Marica deep fault during the Neozoic in the area between Varvara Village, Pazardžic District and the town of Kostenec. Review of the Bulgarian Geological Society 40 (2), 167-173 (in Bulgarian, with English abstract).

Van Dam, H., Mertens, A., Sinkelda, J. 1994. A coded checklist and ecological indicator values of freshwater diatoms from the Netherlands. Netherlands Journal of Aquatic Ecology 28 (1), 117-133.

Vatsev, M., Jordanov, K. 1996. Lithostratigraphy of the Neogene rocks in the Kostenets Basin. Annual of the University of Mining and Geology 41 (1), 7-12 (in Bulgarian, with English abstract).

Wang, C., Lek, S., Lai, Z., Tudesque, L. 2017. Morphology of Aulacoseira filaments as indicator of the aquatic environment in a large subtropical river: the Perl River, China. Ecological indicators 81, 325-332.

Wentworth, C.K. 1922. A scale of grade and class terms for clastic sediments. Journal of Geology 30, 377-392.

Williams, D. 2009. The identity of Tetracyclus constrictus (Bacillariophyceae) and a description of Tetracyclus bradburyii, a new Miocene species. Annales de Paléontologie 95, 37-51.

Zlatarski, G. 1927. Geology of Bulgaria. Sofia University, 201 pp. (in Bulgarian). 